\title{
Application of alkaline industrial wastes in the remediation of acid and metalliferous drainage generated by legacy mine wastes
}

\author{
ANNAH MOYO ${ }^{1}$, ANITA PARBHAKAR-FOX ${ }^{2}$, SEBASTIEN \\ MEFFRE $^{1}$, CLARE B MILLER ${ }^{3}$ AND DAVID R COOKE ${ }^{4}$ \\ ${ }^{1}$ University of Tasmania \\ ${ }^{2}$ University of Queensland \\ ${ }^{3}$ University of Tasmani \\ ${ }^{4}$ CODES, University of Tasmania \\ Presenting Author: annah.moyo@utas.edu.au
}

Alkaline industrial by-products are increasingly used in the remediation of acid and metalliferous drainage (AMD). AMD remediation occurs via acid neutralisation by the carbonate and hydroxide fraction and immobilisation of metals through precipitation and sorption. In this study, green liquor dregs (GLD), wood ash, coal ash and red muds, as well as scallop, mussel and oyster shells were co-disposed with acid-generating mine wastes from six abandoned sites in Tasmania. Initial geochemical static tests classified the mine wastes as potentially acid-forming with NAG $\mathrm{pH}$ ranging between 1.9 - 5.0. The acidneutralizing capacity of the industrial wastes ranged between $35.3-1,017.2\left(\mathrm{~kg} \mathrm{H}_{2} \mathrm{SO}_{4} /\right.$ ton $)$ with shells having the highest and wood ash the lowest capacity. A new bench-scale accelerated kinetic leach test was developed using $55 \mathrm{~mm}$ diameter Buchner funnels for subsequent tests on the combinations of mine wastes with industrial wastes. 82 cells were established with each funnel filled with milled $(<75 \mu \mathrm{m})$ native mine waste (i.e., controls) and 7:3 weight ratio of mine to industrial wastes (both blended and as cover layers). These were irrigated with deionized water every second day for 1 month and every 10 days thereafter until 100 days had elapsed. The blending of the industrial and mine wastes achieved the greatest neutralization, however, the $\mathrm{pH}$ difference when compared to multi-layering and the top covering was mostly $<1.0 \mathrm{pH}$ unit. GLD showed the greatest capacity for neutralising AMD, whilst the wood ash was least effective. Metal analysis of leachates showed that the mine waste controls leached toxic levels of $\mathrm{Al}, \mathrm{As}, \mathrm{Cd}, \mathrm{Cr}, \mathrm{Cu}, \mathrm{Ni}, \mathrm{Pb}$ and $\mathrm{Zn}$. The application of industrial wastes inhibited the leaching of some of the metal(loids) by up to $99.9 \%$, except in the case of wood ash. Overall, our results indicate that metal(loid)s leachability is mostly influenced by $\mathrm{pH}$, but the leachability of As increases with increasing $\mathrm{pH}$. Industrial wastes are therefore potentially a cheap and environmentally sustainable alternative for neutralising AMD and immobilising toxic metal(loid)s. 